\title{
Modern and Fossil Diatom Assemblages from Bol'shoy Lyakhovsky Island (New Siberian Archipelago, Arctic Siberia)
}

\author{
O. V. Palagushkina ${ }^{a, *}$, S. Wetterich ${ }^{b}$, L. Schirrmeister ${ }^{b}$, and L. B. Nazarova ${ }^{a, b, c}$ \\ ${ }^{a}$ Institute of Management, Economics and Finance, Kazan Federal University, Kazan, 420008 Russia \\ ${ }^{b}$ Alfred Wegener Institute, Helmholtz Center for Polar and Marine Research, Department of Periglacial Research, \\ Potsdam, 14473 Germany \\ ${ }^{c}$ University of Potsdam, Institute of Earth and Environmental Science, Potsdam-Golm, 14476 Germany \\ *e-mail: opalagushkina@mail.ru \\ Received@@@@@,@@@; in final form,@@@@@,@@@@
}

\begin{abstract}
This article discusses the results of a taxonomic and ecological investigation into diatoms from polygonal ponds and quaternary permafrost deposits of Bol'shoy Lyakhovsky Island (New Siberian Archipelago) and the reconstruction of climatic changes on the island during Late Pleistocene/Holocene transition using fossil diatom assemblages from the permafrost deposits. The taxonomic list of diatoms includes 159 diatom species. The main ecological factors that determine the distribution of diatoms in the investigated data set are mean air temperature in July, $\mathrm{pH}$, conductivity, water depth, and the concentration of $\mathrm{Si}^{4+}$ and $\mathrm{Al}^{3+}$. An increase in water depth and stable lacustrine conditions in the Lateglacial-Holocene in the ancient thermokarst lake relate to Lateglacial warming before $11860 \pm 160$ years BP and during the early Holocene between $11210 \pm 160$ and $7095 \pm 60$ years BP.
\end{abstract}

Keywords: high Arctic, Bol'shoy Lyakhovsky Island, diatoms, ecological factors, Pleistocene, Holocene DOI: $10.1134 /$ S1995425517040060

\section{INTRODUCTION}

The territory of the high Arctic zone $\left(71^{\circ} \mathrm{N}\right.$ and higher), which includes the New Siberian Islands, has extreme climatic conditions (long winters, constant low temperatures, and short growing seasons). Therefore, this zone remains almost unaffected by anthropogenic impact and consequently has an exceptional potential to be used for the reconstruction of historical environment (Cremer, Wagner, 2003; Palagushkina et al., 2014, Frolova, 2016). Palaeoarchives of such arctic conditions are benthic sediments in both modern aquatic ecosystems and permafrost sequences formed on the place of existing lakes (Wetterich et al., 2009 a). Diatoms are widely used as palaeoindicators but remain relatively poorly studied in the palaeoarchives of the high Arctic zone of Siberia. Some literature data on the quaternary deposits of diatoms was collected on both islands of the New Siberian Archipelago, namely, Bol'shoy Lyakhovsky Island (Romanovsky, 1958; Rapoport, Romanovsky, 1959; Pirumova, 1968; Archangelov et al., 1996; Kunitsky, 1998; Grigor'ev, Kunitsky 2000; Andreev et al., 2004; Andreev et al., 2009, Andreev et al., 2011) and Zhokhov Island (Anisimov et al., 2009a; Anisimov et al., 2009b). The investigation into species composition and ecological parameters of diatoms in the high Arctic will provide additional data for regional databases and will help increase the accuracy of paleoecological reconstructions.

The purpose of this work is to study the taxonomic composition and ecological features of diatoms in the palaeoarchives of Bol'shoy Lyakhovsky Island and identify the main ecological factors that determine the diatom communities nowadays and during the last transition between glacial and interglacial conditions.

\section{MATERIALS AND METHODS}

The complex research of the Russian and German expedition team was performed on the Bol'shoy Lyakhovsky Island in July 2007 (Fig. 1). According to climatic zoning, the territory of studies belongs to the arctic zone and is characterized by great difference in the amount of sunlight in winter and summer, 9-month-long cold period, and a frostless period of $30-45$ days. The mean temperature in January varies from -32 to $-35^{\circ} \mathrm{C}$; the mean temperature in July varies from +6 to $+8^{\circ} \mathrm{C}$. The mean annual precipitation rate is less than $150 \mathrm{~mm}$; the summer season accounts for more than $60 \%$ of them (Gavrilova, 1973). Thermokarst lakes are rather rare in the modern relief 


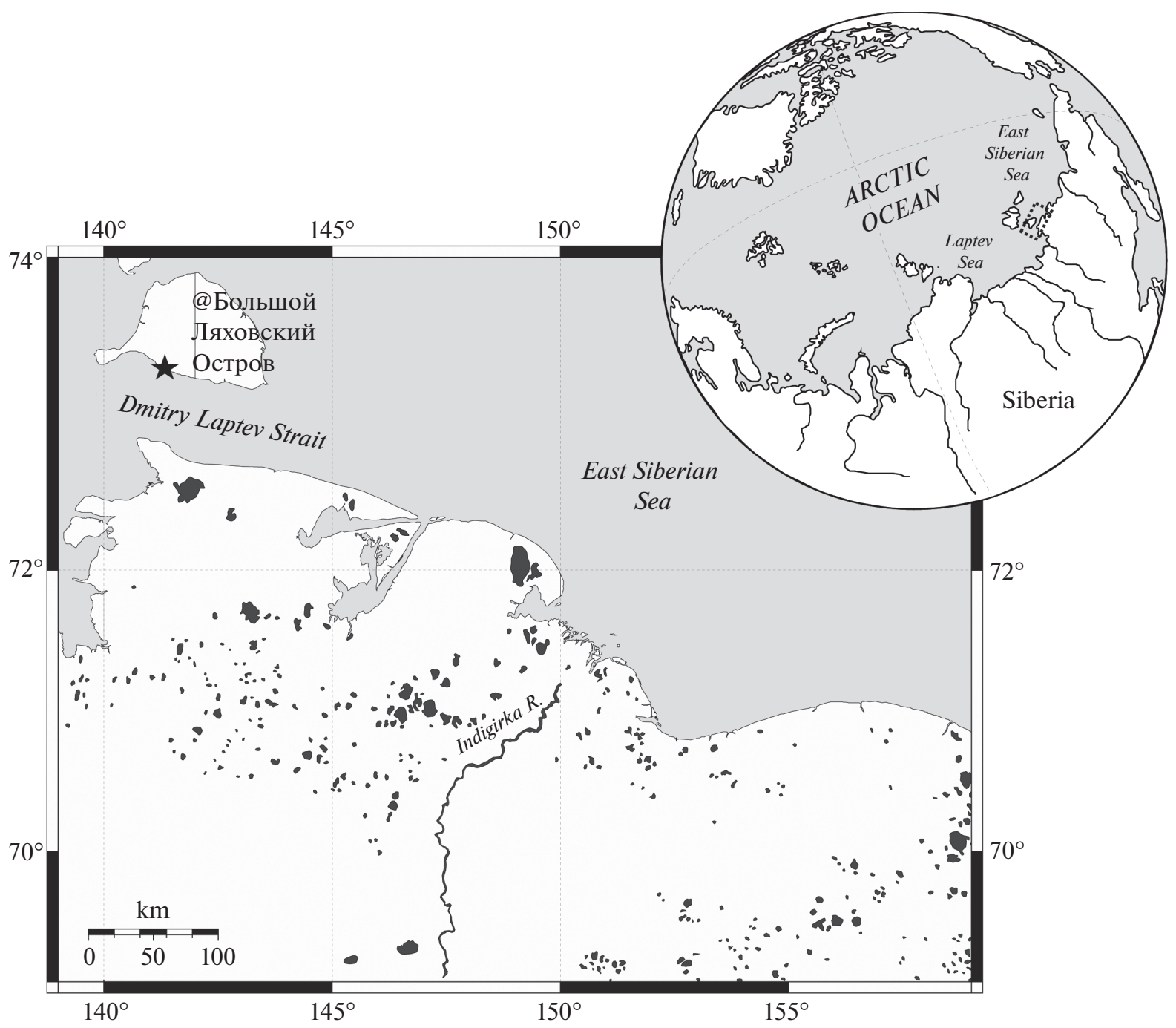

Fig. 1. Study site on Bol'shoy Lyakhovsky Island.

of the island, but thermoerosional valleys and polygonal ponds are common parts of its periglacial landscape (Wetterich et al., 2009b).

We studied 15 polygonal ponds (LAP 1d-15) in different landscape elements of the southern coastal zone of Bol'shoy Lyakhovsky Island $\left(73^{\circ} \mathrm{N}, 141^{\circ} \mathrm{E}\right)$. The study material included water samples and the samples of superficial benthic sediments consisting of silty or sandy matter with some detritus. We measured water temperature, $\mathrm{pH}$, and conductivity (Wetterich et al., 2009 a; Nazarova et al., 2011). The chemical composition of water was hydrocarbonate-chloride (Wetterich et al., 2008) with a low mineralization rate (Alekin, 1970) and low hardness. The water $\mathrm{pH}$ was neutral or slightly alkaline (Palagushkina et al., 2012a; Palagushkina et al., 2013). Daily monitoring of water temperature in LAP-01d water body showed that it mainly depends on air temperature (Fig. 2), which varied from -1 to $+25^{\circ} \mathrm{C}$, while water temperature varied from +3 to $+17^{\circ} \mathrm{C}$. More detailed data on studied polygonal ponds of the island is presented in (Palagushkina et al., 2012a).

The samples of frozen deposits for micropaleontological analysis were collected in a composite profile L7-08 on a cliff situated near the Laptev Strait. The profile consisted of subprofiles $A B$ and $C D$ (Fig. 3), separate samples of which were analyzed by radiocarbon dating using accelerator mass spectrometry (AMS). The geochronological, lithological, and first paleontological data of the L7-08 profile based on the analysis of pollen and ostracods have already been published (Wetterich et al., 2009a). Based on geochronological, sedimentological, biochemical, and cryolithological measurements, we divided the horizons into three groups: taberal (A), which consists of late Pleistocene complex; lacustrine (B and C), which consists of lateglacial and early Holocene sediments of thermokarst lake and contains mollusc shells, ostracods, and wood 


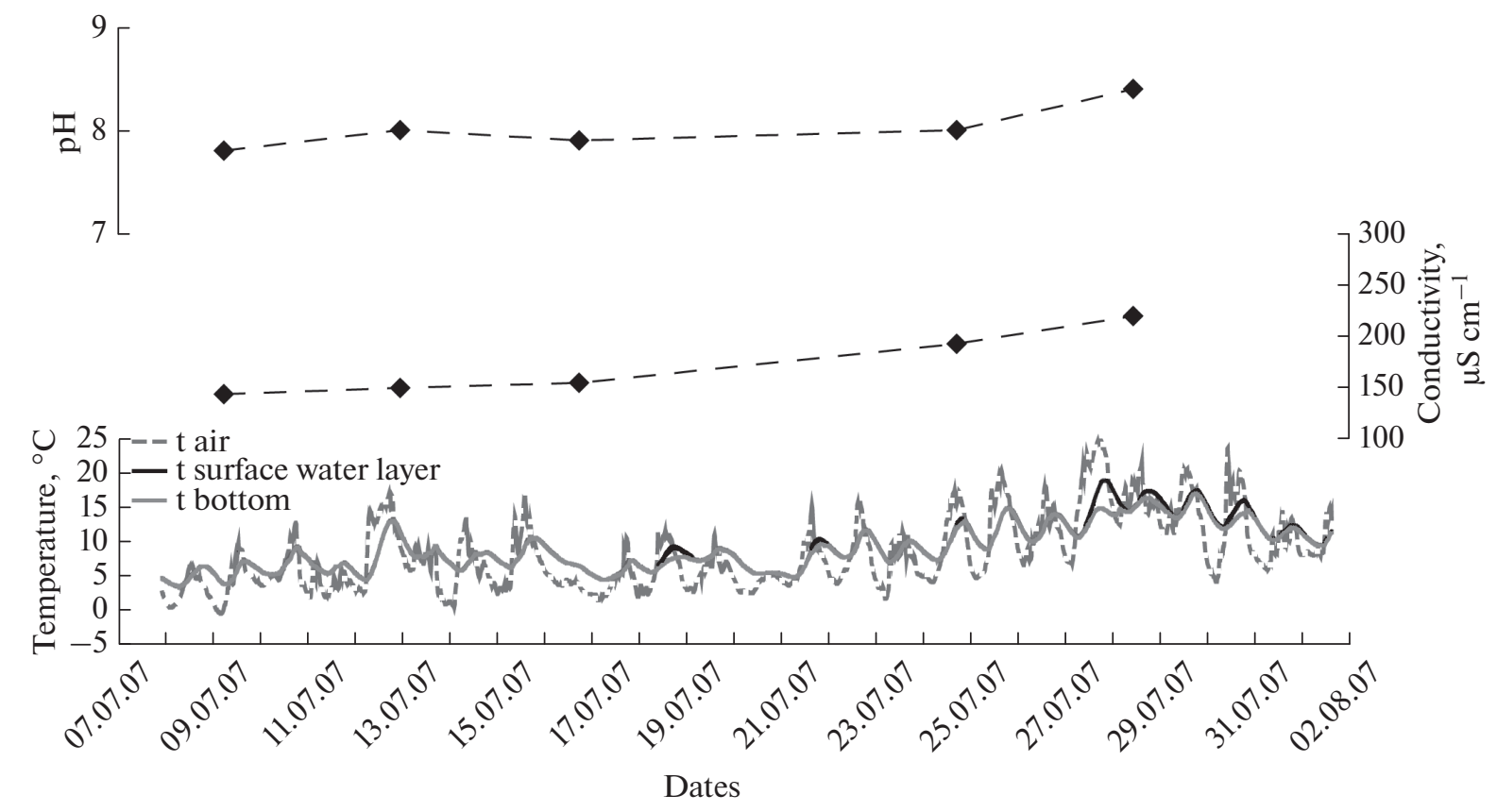

Studied polygonal waterbody

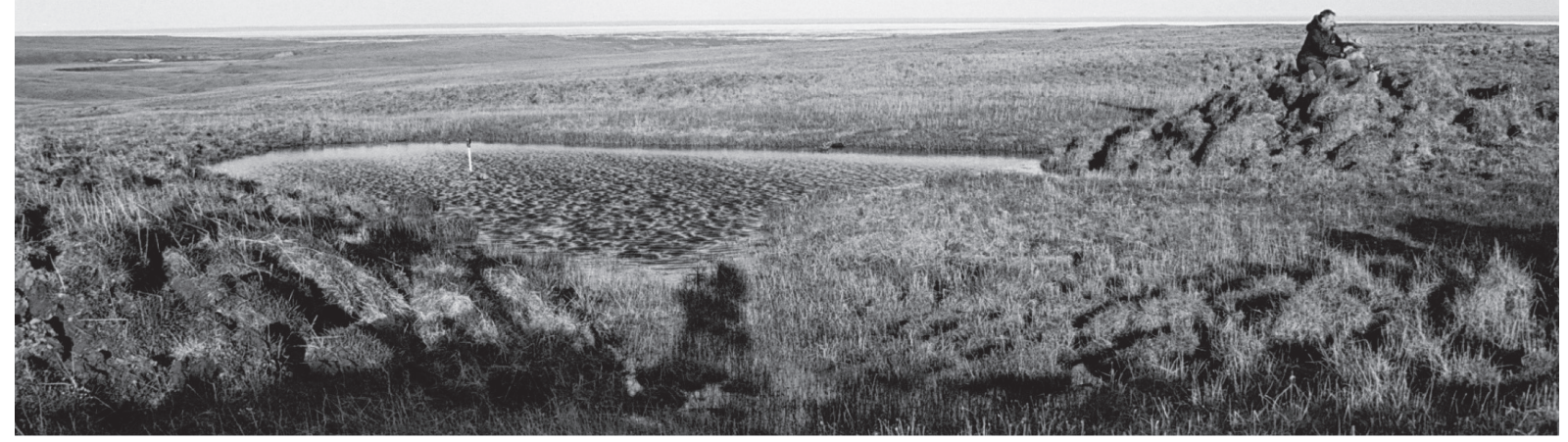

Fig. 2. Monitoring of air temperature, water temperature, $\mathrm{pH}$, and conductivity in a polygonal pond LAP-01d on Bol'shoy Lyakhovsky Island.

fragments; and waterlogged (D), which was accumulated in tundra during Holocene (Wetterich et al., 2009 a) (Fig. 3).

The samples of benthic sediments of polygonal ponds and frozen deposits were treated using the water bath method (Battarbee, 1986) in the laboratory of Alfred Wegener Institute (Potsdam, Germany). For the preparation of slides, we used high refracting Naphrax resin. The species were identified using Russian and other key books (Zabelina et al., 1951; Krammer, Lange-Bertalot, 1986, 1988, 1991a, 1991b). When creating the list of species, we took the latest revisions in systematics into account (Genkal et al., 2013; http://www.algaebase.org/browse/taxonomy/ ?id=77640). The valves were counted by parallel transects up to 500 pieces in a sample of modern sediments and up to 200 pieces in a sample of frozen deposits using Axioplan Zeiss light microscope and immersion oil. The total number of valves was considered to be $100 \%$. Dominant species were those which accounted for $10 \%$ of the total amount or more; subdominants were species which accounted for $5-10 \%$.

The ecological and geographical parameters of diatoms included their habitat, water $\mathrm{pH}$ and salinity, geographical distribution, temperature diapason, and water velocity (Davydova, 1985; Barinova et al., 2006). The similarity of diatom taxonomic composition was estimated using the Sorensen coefficient (Sorensen, 1948).

Statistical analysis was performed using the Canoco 4.5 program and mainly according to the procedures described by Nazarova et al. (Nazarova et al., 2013; Nazarova et al., 2015). The analysis included diatom taxa found in at least one lake with a relative 


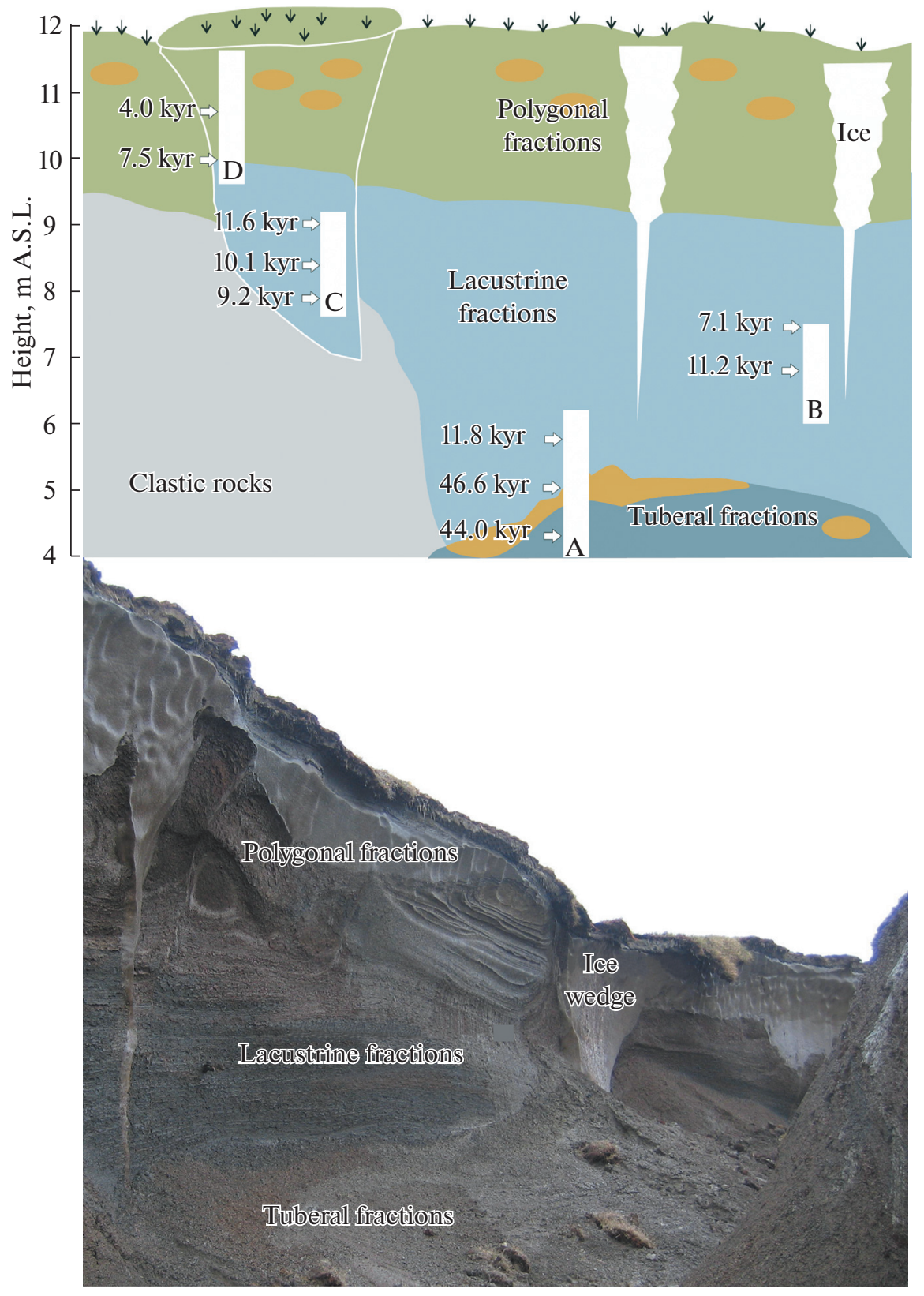

Fig. 3. Composite profile of quaternary permafrost deposits of L7-08 profile on the cliff of Bol'shoy Lyakhovsky Island. Profile horizons: (A) taberal, (B, C) lacustrine, and (D) waterlogged.

abundance of at least $5 \%$. According to the results of DCA, the gradient length of axis was 1.68 units of standard deviation, which means that the linear method of ordination (redundancy analysis, RDA) needs to be used (Birks, 1995; ter Braak, Smilauer, 2002). Statistical analysis included ecological factors such as mean air temperature in July (New et al., 2002), water temperature, water depth, water transparency, conductivity, $\mathrm{pH}$, and the concentration of $\mathrm{Cl}^{-}, \mathrm{SO}_{4}^{2-}, \mathrm{HCO}_{3}^{-}$, $\mathrm{O}_{2}, \mathrm{Si}^{4+}, \mathrm{Ca}^{2+}, \mathrm{Mg}^{2+}, \mathrm{Na}^{+}, \mathrm{Al}^{3+} \mathrm{Fe}_{\text {total }}$. The ecological parameters with a variance inflation factor (VIF) of more than 20 (ter Braak, Šmilauer, 2002) was removed one by one until all the remaining VIF values were lower than 20. The significance of ecological factors that determine the variation of diatom distribution was estimated by the forward selection method. The proportion of modern diatom communities and the samples of frozen deposits of Bol'shoy Lyakhovsky Island was analyzed using an RDA "time-track"; the fossil data was projected in a passive way. The diagram of distribution of diatom taxa in the profile of frozen deposits was built in C2 program (Juggins, 2007) and zoned by cluster analysis in the PAST program (Hammer et al., 2001). 
(a) Biogeographical parameters

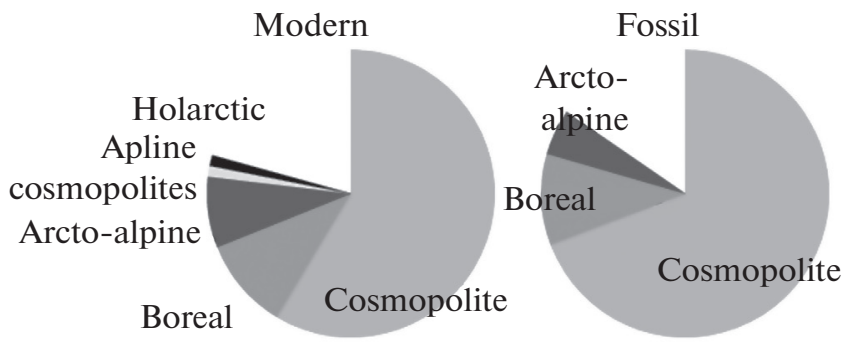

(b) Habitat
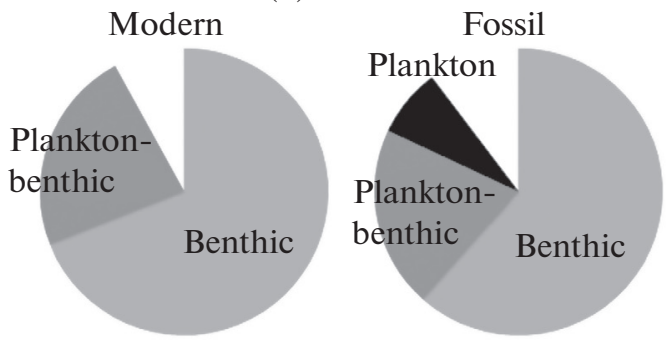

(c) Salinity

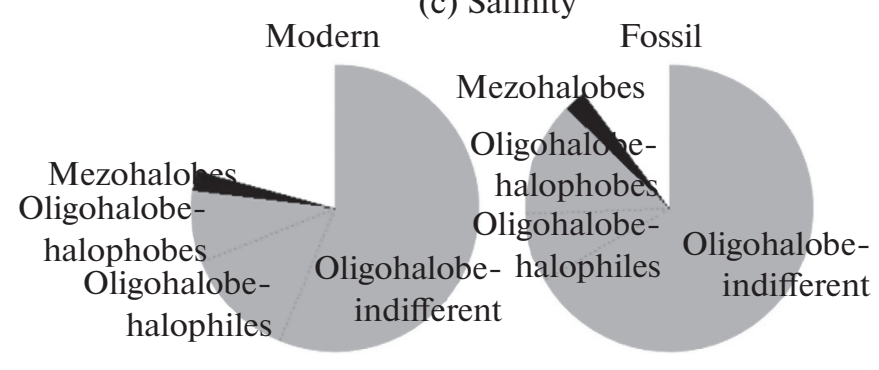

(d) Temperature

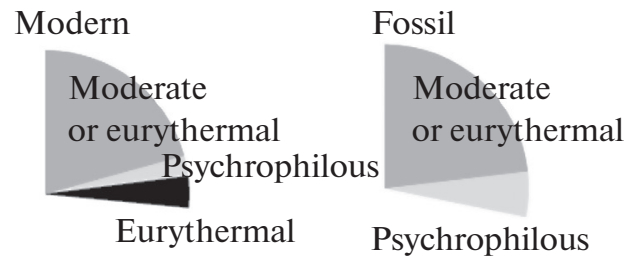

(e) $\mathrm{pH}$

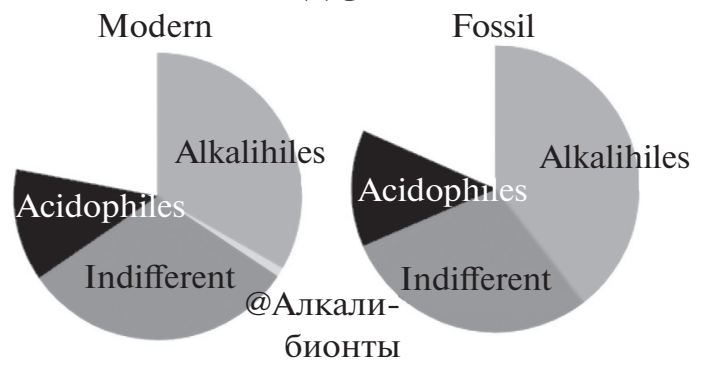

(f) Rheophility

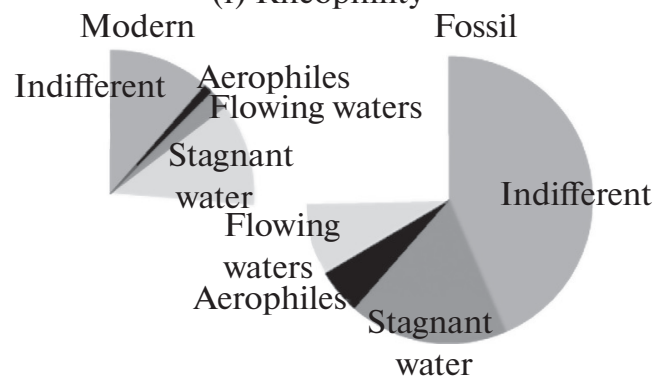

Fig. 4. Ecological and geographical parameters of modern and fossil diatoms of the Bol'shoy Lyakhovsky Island.

\section{RESULTS}

Species Composition of Diatoms and the Factors of Their Distribution

The diatomic flora of modern sediments of 15 polygonal ponds of the Bol'shoy Lyakhovsky Island included 84 species (see table); the number of species per water body varied from 18 to 34 . The dominant species were Achnanthidium minutissimum (Kütz.) Czarnecki, Caloneis amphisbaena (Bory) Cl., Cymbopleura angustata (W.Sm.) Kram., Eunotia praerupta Ehr., E.tenella (Grun.) Hust., Fragilaria brevistriata Grun., Gomphonema angustatum var. angustissima H.F.Van Heurck, Nitzschia frustulum (Kütz.) Grun., N. paleacea (Grun.) Grun., Tabellaria fenestrata (Lyngb.) Kütz., and T. flocculosa (Roth) Kütz.

The ecological and geographical analysis of species composition showed that these are cosmopolitan benthic species either inhabiting stagnant waters or indifferent to water temperature and flow (Fig. 4). Only two psychrophilous species were found: $E$. praerupta Ehr. and Pinnularia brevicostata $\mathrm{Cl}$. The low mineralization rate in most water bodies contributes to the dominance of freshwater oligohalobs; the composition of mezohalobs include Eucocconeis flexella (Kütz.) Meist. and Tryblionella levidensis W.Smith. Most of the species preferred neutral or slightly alkaline $\mathrm{pH}$.

The diatoms of late Pleistocene/Holocene frozen deposits from 17 samples collected in L7-08 thermokarst profile included 40 taxa; the number of taxa varied from 2 to 21 between layers (Fig. 5). These diatoms were mostly cosmopolitan benthic and plankton-benthic species. Only 5\% of species were arcto-alpine, and only $8 \%$ were planktonic. The temperature preferences of most taxa were unknown, or they were indifferent; two of the species were psychrophilous: E. praerupta Ehr. and Gyrosigma acuminatum (Kütz.) Rabenh. The samples found in frozen deposits also induced oligohaline and alkaliphilic conditions (Fig. 4, 5).

The redundancy analysis based on all ecological parameters and the composition of diatoms in modern water bodies and frozen deposits of the Bol'shoy Lyakhovsky Island showed that the level of $\mathrm{Ca}^{2+}, \mathrm{Mg}^{2+}$, $\mathrm{Na}^{+}$and $\mathrm{Cl}^{-}$ions and conductivity correlate with each 
Table 1. Species composition and abundance of diatoms on the Bol'shoy Lyakhovsky Island

\begin{tabular}{|c|c|c|c|c|c|c|}
\hline \multicolumn{2}{|c|}{ Authors } & a & $\mathrm{b}$ & $\mathrm{c}$ & $\mathrm{d}$ & $\mathrm{d}$ \\
\hline \multicolumn{2}{|c|}{ Species } & $\mathrm{f}$ & $\mathrm{f}$ & $\mathrm{f}$ & $\mathrm{m}$ & $\mathrm{f}$ \\
\hline 1 & Achnanthes oblongella Østrup & & & & + & \\
\hline 2 & Achnanthes trinodis (Ralfs) Grunow & & & & + & \\
\hline 3 & Achnanthidium bioretii (H.Germain) Monnier, Lange-Bertalot \& Ector & & & & + & \\
\hline 4 & Achnanthidium minutissimum (Kützing) Czarnecki & & & & + & \\
\hline 5 & Achnantheiopsis delicatula (Kützing) Lange-Bertalot & & & + & & \\
\hline 6 & Actinocyclus normanii (W.Gregory ex Greville) Hustedt & & & & & + \\
\hline 7 & Amphora ovalis (Kützing) Kützing & & & + & & \\
\hline 8 & Amphora libyca Ehrenberg & & & & + & \\
\hline 9 & Aneumastus tuscula (Ehrenberg) D.G.Mann \& A.J.Stickle & & & & & + \\
\hline 10 & Asterionella formosa Hassall & + & + & & & \\
\hline 11 & Aulacoseira granulata (Ehrenberg) Simonsen & + & + & & & + \\
\hline 12 & Aulacoseira granulata var. angustissima (Otto Müller) Simonsen & + & + & & & \\
\hline 13 & Aulacoseira italica (Ehrenberg) Simonsen & + & + & & & \\
\hline 14 & Aulacoseira lacustris (Grunow) Krammer & & & & & + \\
\hline 15 & Aulacoseira valida (Grunow) Krammer & & + & & & + \\
\hline 16 & Aulacoseira distans (Ehrenberg) Simonsen & + & + & & & \\
\hline 17 & Brebissonia lanceolata (C.Agardh) Mahoney \& Reimer & + & & & & \\
\hline 18 & Caloneis amphisbaena (Bory) Cleve & + & + & + & + & \\
\hline 19 & Caloneis leptosoma (Grunow) Krammer & & + & + & & \\
\hline 20 & Caloneis silicula (Ehrenberg) Cleve & & & & + & \\
\hline 21 & Cocconeis pediculus Ehrenberg & & & + & & \\
\hline 22 & Cyclostephanos dubius (Hustedt) Round & & & + & & \\
\hline 23 & Cymbella affinis Kützing & & & + & & \\
\hline 24 & Cymbella aspera (Ehrenberg) Cleve & & & + & & \\
\hline 25 & Cymbella cymbiformis C.Agardh & & & + & + & \\
\hline 26 & Cymbella cistula (Ehrenberg) O.Kirchner & & & & + & \\
\hline 27 & Cymbella heteropleura (Ehrenberg) Kützing & & + & & & \\
\hline 28 & Cymbella gracilis (Ehrenberg) Kützing & & + & & & \\
\hline 29 & Cymbopleura angustata (W.Smith) Krammer & & & & + & \\
\hline 30 & Cymbopleura austriaca (Grunow) Krammer & & & + & & \\
\hline 31 & Cymbopleura incerta (Grunow) Krammer & & & & & + \\
\hline 32 & Cymbopleura lata (Grunow ex Cleve) Krammer & & & + & & \\
\hline 33 & Cymbopleura naviculiformis (Auerswald ex Heiberg) Krammer & & & & + & \\
\hline 34 & Cymbopleura subcuspidata (Krammer) Krammer & & & & + & \\
\hline 35 & Cymbopleura tynnii (Krammer) Krammer & & & & & + \\
\hline 36 & Denticula tenuis Kützing & & & & + & \\
\hline 37 & Diatoma tenuis C.Agardh & & & & + & \\
\hline 38 & Diatoma vulgaris Bory & & + & + & & \\
\hline 39 & Didymosphenia geminata (Lyngbye) Mart.Schmidt & & & + & & \\
\hline 40 & Diploneis elliptica (Kützing) Cleve & & & & & + \\
\hline 41 & Diploneis oblongella (Nägeli ex Kützing) Cleve-Euler & & & & + & \\
\hline 42 & Diploneis puella (Schumann) Cleve & & & & + & \\
\hline 43 & Encyonema alpinum (Grunow) D.G.Mann & & & & + & \\
\hline
\end{tabular}


Table 1 (Contd.)

\begin{tabular}{|c|c|c|c|c|c|c|}
\hline \multicolumn{2}{|c|}{ Authors } & a & $\mathrm{b}$ & $\mathrm{c}$ & $\mathrm{d}$ & d \\
\hline \multicolumn{2}{|c|}{ Species } & $\mathrm{f}$ & $\mathrm{f}$ & $\mathrm{f}$ & $\mathrm{m}$ & $\mathrm{f}$ \\
\hline 44 & Encyonema hebridicum Grunow ex Cleve & + & + & + & & \\
\hline 45 & Eucocconeis flexella (Kützing) Meister & & & & + & \\
\hline 46 & Eucocconeis laevis (Østrup) Lange-Bertalot & & & & + & \\
\hline 47 & Encyonema latens (Krasske) D.G.Mann & & & & + & \\
\hline 48 & Encyonema mesianum (Cholnoky) D.G.Mann & & & & + & + \\
\hline 49 & Encyonema minutum (Hilse) D.G.Mann & & & & + & \\
\hline 50 & Encyonema paucistriatum (Cleve-Euler) D.G.Mann & & & & + & \\
\hline 51 & Encyonema perpusillum (Cleve-Euler) D.G.Mann & & + & & & \\
\hline 52 & Encyonema silesiacum (Bleisch) D.G.Mann & + & + & + & + & + \\
\hline 53 & Eunotia arcus Ehrenberg & & + & & & \\
\hline 54 & Eunotia bidens Ehrenberg & & & + & & \\
\hline 55 & Eunotia bigibba Kützing & & + & + & & \\
\hline 56 & Eunotia bilunaris (Ehrenberg) Schaarschmidt & + & + & + & + & + \\
\hline 57 & Eunotia denticulata var. denticulata (Brébisson ex Kützing) Rabenhorst & & & + & & \\
\hline 58 & Eunotia diodon Ehrenberg & & + & + & & \\
\hline 59 & Eunotia exigua (Brébisson ex Kützing) Rabenhorst & + & + & + & + & \\
\hline 60 & Eunotia faba Ehrenberg & & & + & + & \\
\hline 61 & Eunotia fallax A.Cleve & + & + & & & \\
\hline 62 & Eunotia inflata (Grunow) Norpel-Schempp \& Lange-Bertalot & + & + & & & \\
\hline 63 & Eunotia monodon Ehrenberg & & & + & & \\
\hline 64 & Eunotia parallela Ehrenberg & & & & + & \\
\hline 65 & Eunotia papilio (Ehrenberg) Grunow & + & + & & & \\
\hline 66 & Eunotia pectinalis (Kützing) Rabenhorst & & + & + & & \\
\hline 67 & Eunotia praerupta Ehrenberg & + & + & + & + & + \\
\hline 68 & Eunotia satelles (Nörpel-Schempp \& Lange-Bertalot) Nörpel-Schempp \& & ge-1 & alot & + & & \\
\hline 69 & Eunotia septentrionalis Østrup & & & + & & \\
\hline 70 & Eunotia sudetica Otto Müller & & & + & & \\
\hline 71 & Eunotia tenella (Grunow) Hustedt & + & + & + & + & \\
\hline 72 & Eunotia triodon Ehrenberg & & + & & & \\
\hline 73 & Fragilaria bidens Heiberg & & & & + & \\
\hline 74 & Fragilaria brevistriata Grunow & & & & + & \\
\hline 75 & Fragilaria capucina Desmazières & & & & + & \\
\hline 76 & Fragilariforma constricta (Ehrenberg) D.M.Williams \& Round & & & & + & \\
\hline 77 & Fragilaria tenera var. nanana (Lange-Bertalot) Lange-Bertalot \& S.Ulrich & & & & + & \\
\hline 78 & Fragilaria tenera $(\mathrm{W}$. Smith) Lange-Bertalot & & & & + & \\
\hline 79 & Fragilariforma virescens (Ralfs) D.M.Williams \& Round & & & & + & \\
\hline 80 & Fragilaria virescens var. exigua Grunow & & & & & + \\
\hline 81 & Fragilaria sp. & & & & & + \\
\hline 82 & Frustulia rhomboides (Ehrenberg) De Toni & & & & & + \\
\hline 83 & Frustulia spicula Amossé & & & & + & \\
\hline 84 & Frustulia vulgaris (Thwaites) De Toni & & & & + & \\
\hline 85 & Gomphonema acuminatum Ehrenberg & & & + & + & \\
\hline 86 & Gomphonema angustum C.Agardh & & & + & & \\
\hline
\end{tabular}


Table 1 (Contd.)

\begin{tabular}{|c|c|c|c|c|c|c|}
\hline Author & & $\mathrm{a}$ & $\mathrm{b}$ & $\mathrm{c}$ & $\mathrm{d}$ & $\mathrm{d}$ \\
\hline Species & & f & $\mathrm{f}$ & $\mathrm{f}$ & $\mathrm{m}$ & $\mathrm{f}$ \\
\hline 87 & Gomphonema angustatum var. angustissima H.F.Van Heurck & & & & + & + \\
\hline 88 & Gomphonema turris Ehrenberg & & & + & & \\
\hline 89 & Gomphonema gracile Ehrenberg & & & & + & \\
\hline 90 & Gomphonema minutum (C.Agardh) C.Agardh & & & & + & \\
\hline 91 & Gomphonema olivaceum (Hornemann) Brébisson & & + & + & + & + \\
\hline 92 & Gomphonema olivaceum var. minutissimum Hustedt & & & & + & \\
\hline 93 & Gomphonema parvulum (Kützing) Kützing & & & + & + & + \\
\hline 94 & Gomphonema truncatum Ehrenberg & & + & & + & + \\
\hline 95 & Gyrosigma acuminatum (Kützing) Rabenhorst & & & & & + \\
\hline 96 & Gyrosigma attenuatum (Kützing) Rabenhorst & & & + & & \\
\hline 97 & Hantzschia amphioxys (Ehrenberg) Grunow & + & + & + & + & + \\
\hline 98 & Hantzschia virgata (Roper) Grunow & & + & & & \\
\hline 99 & $\begin{array}{l}\text { Humidophila contenta (Grunow) Lowe, Kociolek, J.R.Johansen, Van de Vijver, } \\
\text { Lange-Bertalot \& Kopalová }\end{array}$ & & & & + & \\
\hline 100 & Navicula amphibola Cleve & + & + & + & & \\
\hline 101 & Navicula bryophila Østrup & & & + & & \\
\hline 102 & Navicula cryptocephala Kützing & + & + & + & + & \\
\hline 103 & Navicula lanceolata Ehrenberg & & & + & & \\
\hline 104 & Luticola mutica (Kützing) D.G.Mann & + & + & + & & \\
\hline 105 & Luticola nivalis (Ehrenberg) D.G.Mann & & & & & + \\
\hline 106 & Luticola pseudokotschyi (Lange-Bertalot) Metzeltin \& Lange-Bertalot & + & + & & & \\
\hline 107 & Luticola ventricosa (Kützing) D.G.Mann & & & + & & \\
\hline 108 & Navicula semen Ehrenberg & + & & & & \\
\hline 109 & Navicula rhynchocephala Kützing & & & & + & + \\
\hline 110 & Navicula vulpina Kützing & & & & + & \\
\hline 111 & Neidium affine (Ehrenberg) Pfitzer & & & & & + \\
\hline 112 & Neidium bisulcatum (Lagerstedt) Cleve & & & & + & \\
\hline 113 & Neidium iridis (Ehrenberg) Cleve & & + & & + & + \\
\hline 114 & Nitzschia bulnheimiana (Rabenhorst) H.L.Smith & & & & + & \\
\hline 115 & Nitzschia commutatoides Lange-Bertalot & & & & + & \\
\hline 116 & Nitzschia frustulum (Kützing) Grunow & & & & + & \\
\hline 117 & Nitzschia frustulum var. tenella Grunow & & & & + & \\
\hline 118 & Nitzschia linearis W.Smith & & & & + & \\
\hline 119 & Nitzschia gracilis Hantzsch & & & & + & \\
\hline 120 & Nitzschia palea (Kützing) W.Smith & & & & + & \\
\hline 121 & Nitzschia paleacea (Grunow) Grunow & & & & + & \\
\hline 122 & Nitzschia subtilis (Kützing) Grunow & & & & + & \\
\hline 123 & Nitzschia vermicularis (Kützing) Hantzsch & & & & & + \\
\hline 124 & Nitzschia sp. & & & & & + \\
\hline 125 & Orthoseira roeseana (Rabenhorst) O'Meara & & & & + & + \\
\hline 126 & Pinnularia alpina W.Smith & & & & + & \\
\hline 127 & Pinnularia borealis Ehrenberg & + & + & + & + & + \\
\hline 128 & Pinnularia brevicostata Cleve & & & + & + & \\
\hline
\end{tabular}


Table 1 (Contd.)

\begin{tabular}{|c|c|c|c|c|c|c|}
\hline \multicolumn{2}{|c|}{ Authors } & $\mathrm{a}$ & $\mathrm{b}$ & $\mathrm{c}$ & $\mathrm{d}$ & $\mathrm{d}$ \\
\hline \multicolumn{2}{|c|}{ Species } & $\mathrm{f}$ & $\mathrm{f}$ & $\mathrm{f}$ & $\mathrm{m}$ & $\mathrm{f}$ \\
\hline 129 & Pinnularia divergens $\mathrm{W} . \mathrm{Smith}$ & & & + & & \\
\hline 130 & Pinnularia intermedia (Lagerstedt) Cleve & + & + & & + & \\
\hline 131 & Pinnularia interrupta W.Smith & & & + & + & \\
\hline 132 & Pinnularia gentilis (Donkin) Cleve & & + & & & \\
\hline 133 & Pinnularia gibba Ehrenberg & & & + & & \\
\hline 134 & Pinnularia lata (Brébisson) W.Smith & + & + & + & & + \\
\hline 135 & Pinnularia microstauron (Ehrenberg) Cleve & & + & & + & + \\
\hline 136 & Pinnularia subcapitata W.Gregory & & + & & & \\
\hline 137 & Pinnularia viridis (Nitzsch) Ehrenberg & + & + & + & + & + \\
\hline 138 & Platessa conspicua (Ant.Mayer) Lange-Bertalot & & & & & + \\
\hline 139 & Placoneis elginensis (W.Gregory) E.J.Cox & & & & & + \\
\hline 140 & Placoneis placentula (Ehrenberg) Mereschkowsky & & & + & & \\
\hline 141 & Psammothidium levanderi (Hustedt) Bukhtiyarova \& Round & & & & + & \\
\hline 142 & Rhoicosphenia abbreviata (C.Agardh) Lange-Bertalot & & & & + & \\
\hline 143 & Sellaphora pupula (Kützing) Mereschkovsky & & + & + & + & \\
\hline 144 & Stauroneis anceps Ehrenberg & + & + & & + & + \\
\hline 145 & Stauroneis phoenicenteron (Nitzsch) Ehrenberg & + & + & + & + & + \\
\hline 146 & Staurosirella pinnata (Ehrenberg) D.M.Williams \& Round & & & & + & + \\
\hline 147 & Stephanodiscus alpinus Hustedt & & & & + & + \\
\hline 148 & Stephanodiscus minutulus (Kützing) Cleve \& Möller & & & + & & \\
\hline 149 & Stephanodiscus niagarae Ehrenberg & & & & & + \\
\hline 150 & Stephanodiscus rotula (Kützing) Hendey & + & + & & & \\
\hline 151 & Surirella angusta Kützing & & & & & + \\
\hline 152 & Surirella minuta Brébisson ex Kützing, nom. illeg. & & & & + & \\
\hline 153 & Tabellaria fenestrata (Lyngbye) Kützing & & & + & + & \\
\hline 154 & Tabellaria flocculosa (Roth) Kützing & + & + & & + & \\
\hline 155 & Tabularia fasciculata (C.Agardh) D.M.Williams \& Round & & & & + & \\
\hline 156 & Tryblionella debilis Arnott ex O’Meara & & & & + & \\
\hline 157 & Tryblionella levidensis W.Smith & & & & + & \\
\hline 158 & Tetracyclus emarginatus (Ehrenberg) W.Smith & & & & & \\
\hline \multirow[t]{2}{*}{159} & Ulnaria ulna (Nitzsch) Compère & + & + & + & & \\
\hline & Total: & 31 & 48 & 55 & 84 & 40 \\
\hline
\end{tabular}

(a) Rapoport and Romanovsky, 1959 (middle Pleistocene/Holocene);

(b) Pirumova et al., 1968 (middle Pleistocene/Holocene);

(c) Andreev et al., 2009 (late Pleistocene/Holocene);

(d) Palagushkina et al. (late Pleistocene/Holocene);

$\mathrm{m}$ indicates modern sediments and $\mathrm{f}$ indicates fossil deposits. 


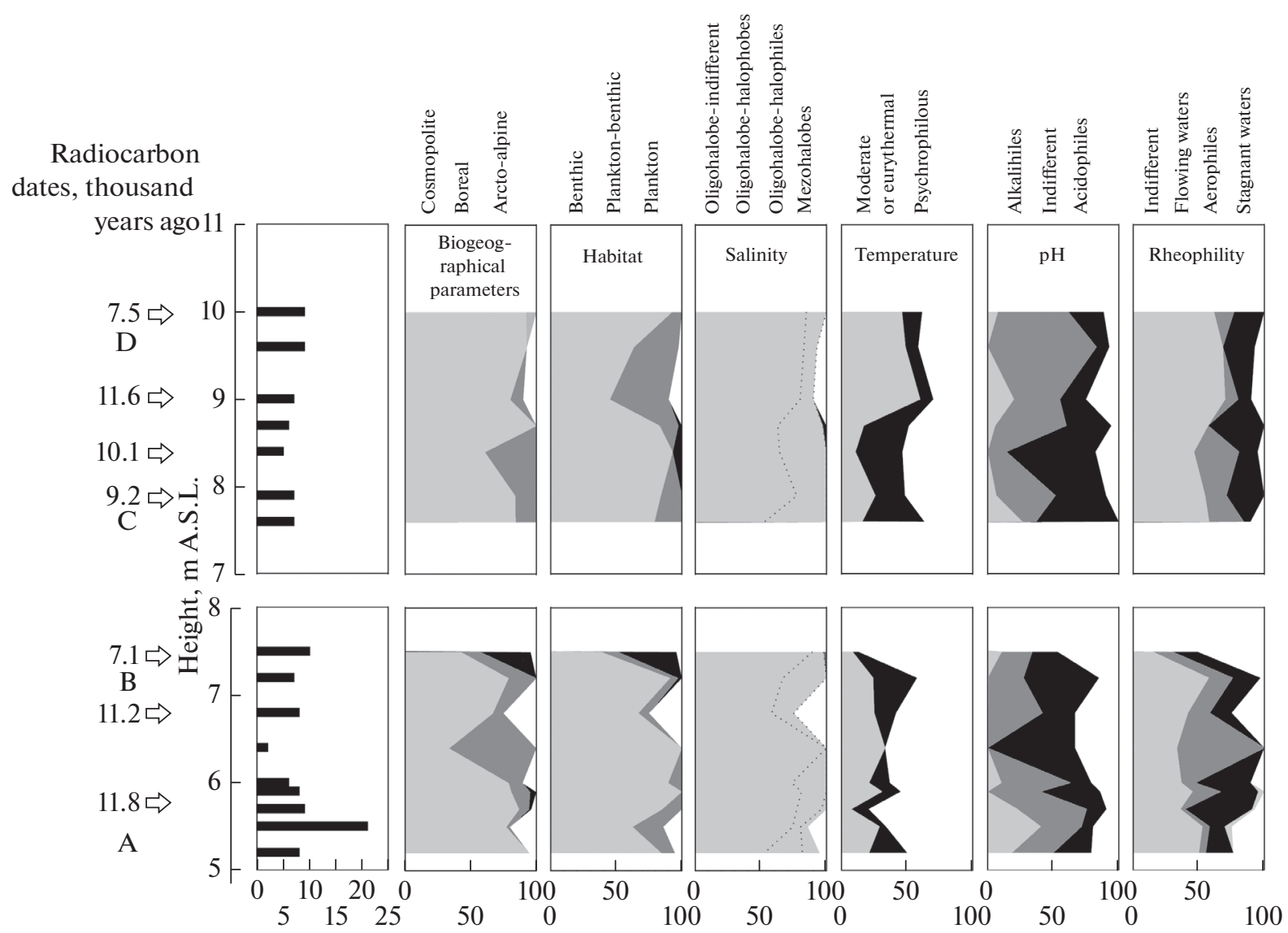

Fig. 5. Number of species and ecological and geographical parameters of diatoms in the horizons of L7-08 profile on Bol'shoy Lyakhovsky Island.

other to a great extent. Monte Carlo test with 499 permutations showed that significant factors that determined the distribution of diatoms $(P \leq 0.05)$ are mean air temperature in July, $\mathrm{pH}$, conductivity, water depth, and the concentration of $\mathrm{Si}^{4+}$ and $\mathrm{Al}^{3+}$.

\section{Reconstruction of Ecological Conditions of Lateglacial Period of Pleistocene/Holocene}

Both subprofiles of L7-08 thermokarst had the same geological age. However, the horizons of upper $\mathrm{CD}$ profile were rearranged in the inverse order (Fig. 3, 5); therefore, this profile was excluded from further paleoecological interpretations. Basing on the age of deposits and the distribution of 14 dominant species, subprofile $\mathrm{AB}$ was divided into two zones: $\mathrm{A}$ and B (Fig. 6).

The samples of zone A $(11860 \pm 160$ years BP, $5.7 \mathrm{~m}$ A.S.L.) belong to late Pleistocene. This zone contained 26 diatom species; the number varied from 6 to 21 . The share of acidophilic and aerophilic species and species indifferent to water flow and salinity increased; the dominant species were Pinnularia borealis Ehr., Hantzschia amphioxys (Ehr.) Grun., E. praerupta Ehr., Stauroneis phoenicenteron (Nitzsch.) Ehr.
The thermokarst water body is supposed to grow shallow and waterlogged as a result of the decreasing temperature of environment.

The samples of zone B $(11210 \pm 160-7095+$ 60 years BP, $6.8-7.5 \mathrm{~m}$ A.S.L.) belong to early Holocene. This zone contained 13 diatom species; the number varied from 7 to 10 . The number of diatom valves in the lower part of this zone was very small, which may indicate that the lake disappeared in early Holocene. The share of valves of planktonic, as well as acidophilic and arcto-alpine species in the middle and upper parts of this zone, increased significantly. In addition to the dominant species of zone A, larger benthic species of the genus Pinnularia (P. lata (Bréb.) W. Smith and P. viridis (Nitzsch) Ehrb.) and some planktonic species (Aulacoseira valida (Grun.) Kramm. and A. lacustris (Grun.) Kramm) were found. This could result from the increasing depth and the formation of stable lacustrine conditions in a thermokarst water body due to an increase in air temperature during the period of the Holocene temperature optimum. This period was determined by palynological analysis performed with the samples aged 9000-10000 years with mean July temperature of 5- 


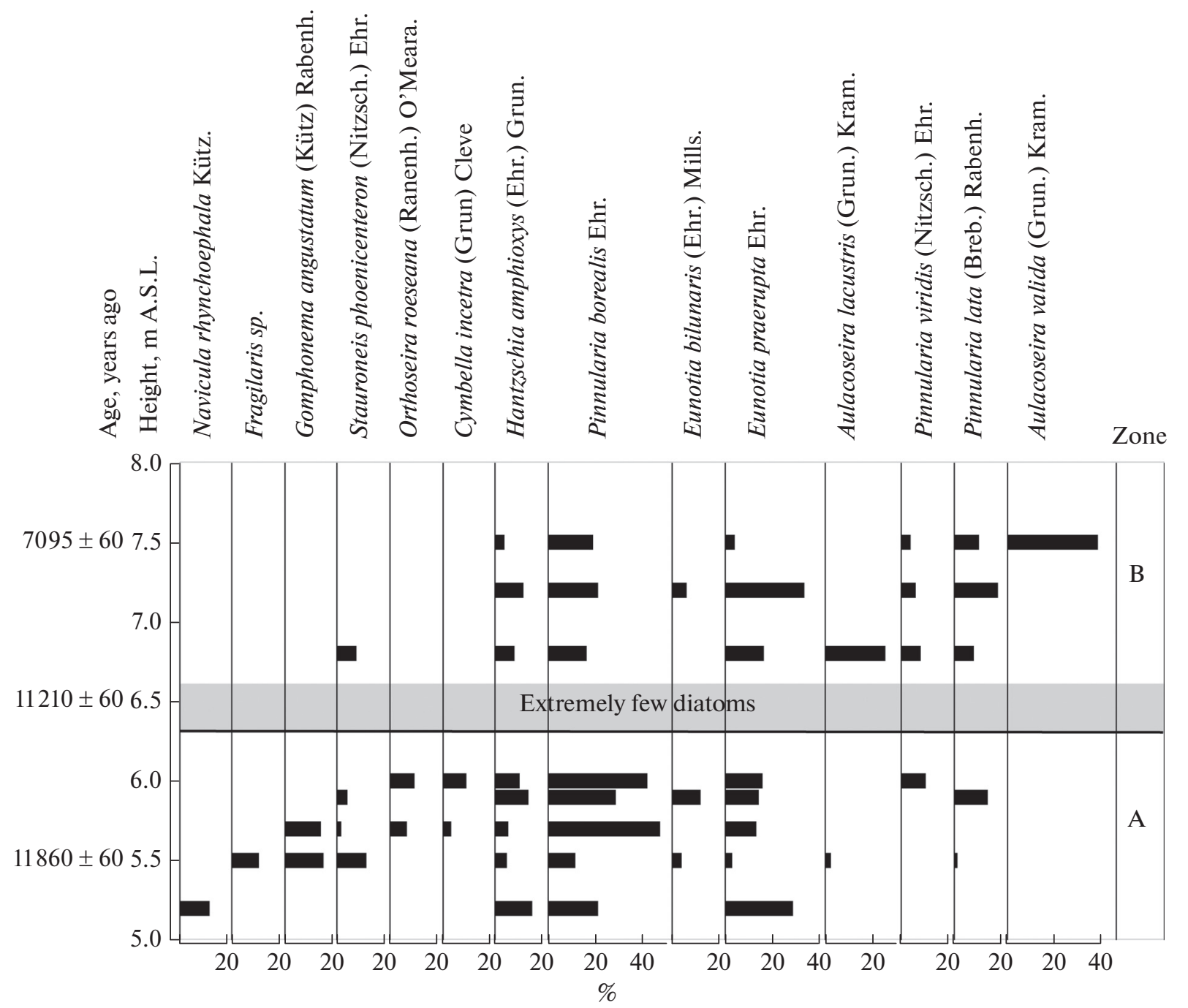

Fig. 6. Distribution of dominant diatom species in the zones of AB subprofile of quaternary permafrost deposits of the L7-08 profile of Bol'shoy Lyakhovsky Island.

$7^{\circ} \mathrm{C}$ in the New Siberian Archipelago (Makeev Pitul'ko, 1991).

\section{DISCUSSION}

First data on the diatoms of late quaternary permafrost deposits of Bol'shoy Lyakhovsky Island were presented by Romanovsky and Rapoport (1959) and Pirumova (1968). These authors identified 31 and 48 diatom species, respectively (see table). Andreev et al. (2009) identified 55 diatom species in the permafrost deposits of late Pleistocene and Holocene. Our study showed that the diatoms of modern sediments of polygonal ponds and quaternary permafrost deposits of the Bol'shoy Lyakhovsky Island are numerous and various. The total taxonomic composition included 159 diatom species: 104 species from frozen deposits and 84 species from modern sediments of polygonal ponds; 19 of them were found more than once, which indicates the high adaptive potential of these species in changing environmental conditions in the quaternary period (see table).

The modern Holocene benthic sediments of diatoms are characterized by high species diversity of the genera Achnanthes (including those renamed Achnanthidium and Psammothidium), Cymbella (including Cymbopleura and Encyonema), Fragilaria (including Fragilariforma and Staurosirella), Gomphonema, and Nitzschia; the predominance of small species with high growth rate; high preferred mineralization rate; and high concentration of $\mathrm{Si}$ and $\mathrm{P}$. The complete absence of planktonic forms is caused by the shallowness of modern polygonal ponds.

A previous investigation into benthic deposits of polygonal tundra water bodies in three subregions of northern Yakutia (Bol'shoy Lyakhovsky Island, the coast of Oygossky Yar, and an area near the settlement of Tiksi) showed that $\mathrm{pH}$, conductivity, and water 


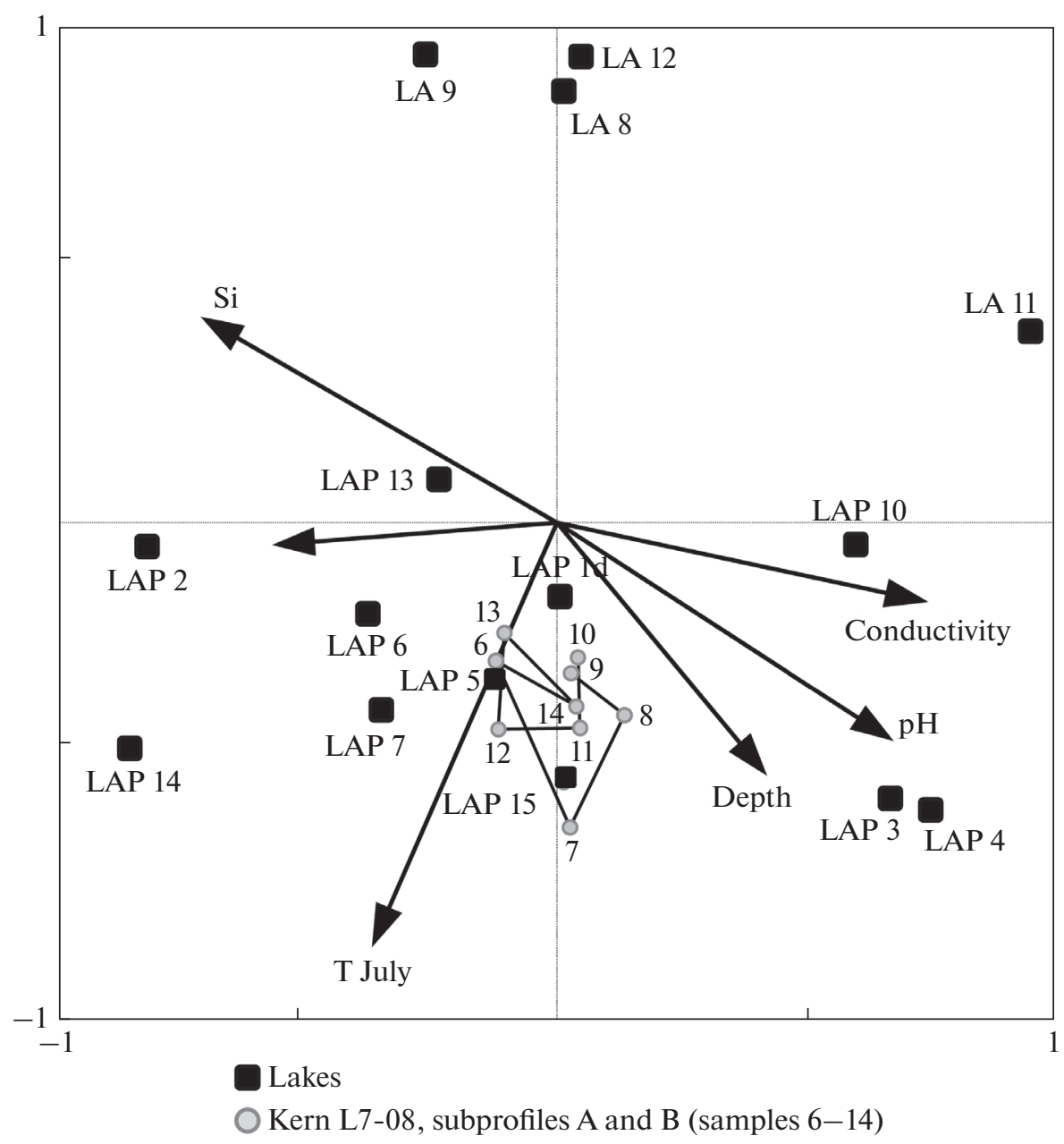

Fig. 7. Distribution of diatom samples in modern polygonal ponds and quaternary frozen deposits of L7-08 profile of Bol'shoy Lyakhovsky Island in relation to the main ecological factors. Note: $(6,7,8,9$, and 10$)$ samples collected in zone A; (11, 12, 13, and 14) samples collected in zone B; LAP 1d to LAP 15: samples of modern sediments of polygonal ponds.

depth are the main ecological factors that determine the species composition of diatoms (Palagushkina et al., 2012 a). In the water bodies of Bol'shoy Lyakhovsky Island, significant factors other than $\mathrm{pH}$, conductivity, and water depth are air temperature in July and the level of $\mathrm{Si}$ and $\mathrm{Al}$ ions. Since the climate of this region is very dry (Gavrilova, 1973) and the studied water bodies are shallow, air temperatures during summer period not only affect water temperature in water bodies (Wetterich et al., 2009a; Palagushkina et al., 2012b) but also determine the depth of thawing process in the active ice layer and evaporation rate and, consequently, the whole acid-base and salt balance of polygonal ponds of the island.

As for the diatom species composition of frozen deposits, most of the species belong to the genera Eunotia, Pinnularia, Aulacoseira, and Navicula (including renamed genera Luticola, Placoneis, and Sellaphora). The species of Eunotia and Pinnularia form freshwater psychrophilous complex of benthic and acidophilic mainly halophobic arcto-alpine and boreal species typical of alas deposits (Belevich et al., 1970; Kagan, 2012). According to literature data, the abundance of these two genera is determined by low concentrations of dissolved calcium, magnesium, carbonate, and hydrocarbonate ions and low $\mathrm{pH}$ values (Van Dam et al., 1994; Potapova et al., 2003; Stenina, 2008). In arctic water bodies with low mineralization rate, $\mathrm{pH}$ becomes the most important factor that affects the development of diatom communities (Rouillard et al., 2012).

Another complex, which mainly consists of alkaliphilic species of the genera Aulacoseira and Navicula, inhabits the alluvium of floodplain facies; this complex differs from the previous one by the presence of planktonic forms (Belevich et al., 1970). The development of Aulacoseira ssp. is usually associated with a decrease in the duration of ice cover caused by warming conditions, increasing duration and level of open water, and higher concentrations of Si compounds, the availability of which depends on water turbulence (Rühland et al.,2005; Paul et al., 2010). Both com- 
plexes of diatoms in frozen deposits indicate the presence of water ecosystems in late Pleistocene and the dynamics of environmental conditions of the past.

The comparison of species composition of diatom deposits in polygonal ponds and quaternary permafrost sequences showed that modern and fossil floras of the island are highly similar (by 40.3\%).

A high importance of air temperature for the formation of conditions of algal development is observed in a modern shallow LAP 5 water body with low mineralization rate and L7-08 thermokarst associated with the late Pleistocene (sample 6, $5.2 \mathrm{~m}$ A.S.L.) and Holocene (samples 13-14, 7.2-7.5 m A.S.L.) (Fig. 7). These findings suggest that conditions formed in a thermokarst water body were similar to modern conditions.

Lacustrine conditions resulting from dramatic climate warming in the late Pleistocene in 12000 years BP and reconstructed by us provided the active development of a thermokarst on the Bol'shoy Lyakhovsky Island (Anisimov et al., 2009a; Anisimov et al, 2009b). These conditions are also evidenced by a palynological analysis of samples of the same age collected in the L7-08 profile, including such palynomorphes as the spores of Pediastrum and Botryococcus (Wetterich et al., 2009a). The presence of a well-formed thermokarst water body and stable lacustrine conditions before the start of the Holocene is also proved by a high number of ostracod valves in the horizons aged about 12500 years BP and $11600-10100$ years BP (Wetterich et al., 2009a).

\section{CONCLUSIONS}

Our study provided new data on the taxonomic and ecological parameters of diatoms in the palaeoarchives of Bol'shoy Lyakhovsky Island and showed that modern and fossil diatomic flora is characterized by the dominance of cosmopolitan benthic alkaliphilic oligohalobs indifferent to water temperature and flow. The presence of some species in both fossil and modern sediments suggests that the diatoms of this region have a high adaptive potential in changing environmental conditions in the quaternary period. The main ecological factors that affect the distribution of modern and fossil diatoms are air temperature, $\mathrm{pH}$, conductivity, water depth, and the level of $\mathrm{Si}$ and $\mathrm{Al}$ ions. An increase in water depth and stable lacustrine conditions in the Lateglacial-Holocene in an ancient thermokarst lake relate to Lateglacial warming before $11860 \pm 160$ years BP and during the early Holocene between $11210 \pm 160$ to $7095 \pm 60$ years BP.

\section{ACKNOWLEDGMENTS}

This study was supported by the Russian Scientific Foundation, project no. 16-17-10118; by the Arctic Ecological Network international project (Arc-EcoNet, BMBF 01DJ 14003); and by the government (a subsidy for Kazan Federal University aimed at its higher competitiveness in the sphere of world education and science). The creation of databases was supported by DAAD (Mikhail Lomonosov program, A0972849), Germany. We thank Russian and German colleagues for their help in field studies and laboratory tests.

\section{REFERENCES}

Alekin, O.A., Osnovy gidrokhimii (Fundamentals of Hydrochemistry), Leningrad: Gidrometeoizdat, 1970. AlgaeBase. http://www.algaebase.org/browse/taxonomy/ ?id $=77640$.

Andreev, A.A., Grosse, G., Schirrmeister, L., Kuzmina, S.A., Novenko, E.Y., Bobrov, A.A., Tarasov, P.E., Kuznetsova, T.V., Krbetschek, M., Meyer, H., and Kunitsky, V.V., Late Saalian and Eemian palaeoenvironmental history of the Bol'shoy Lyakhovsky Island (Laptev Sea region, Arctic Siberia), Boreas, 2004, vol. 33, pp. 319-348.

Andreev, A.A., Grosse, G., Schirrmeister, L., Kuznetsova, T.V., Kuzmina, S.A., Bobrov, A.A., Tarasov, P.E., Novenko, E.Y., Meyer, H., Derevyagin, A.Y., Kienast, F., Bryantseva, A., and Kunitsky, V.V., Weichselian and Holocene palaeoenvironmental history of the Bol'shoy Lyakhovsky Island, New Siberian Archipelago, Arctic Siberia, Boreas, 2009, vol. 38, pp. 72-110.

Andreev, A.A., Schirrmeister, L., Tarasov, P.E., Ganopolski, A., Brovkin, V., Siegert, C., Wetterich, S., and Hubberten, H.-W., Vegetation and climate history in the Laptev Sea region (Arctic Siberia) during late Quaternary inferred from pollen records, Quat. Sci. Rev., 2011, vol. 30, pp. 2182-2199.

Anisimov, M.A., Ivanova, V.V., Pushina, Z.V., and Pitul'ko, V.V., Lagoon deposits of the Zhokhova Island: age, development conditions and role in paleogeographic reconstructions of the region of Novosibirsk islands, Izv. Ross. Akad. Nauk, Ser. Geogr., 2009a, no. 4, pp. 107-119.

Anisimov, M.A., Pavlova, E.Yu., and Pitul'ko, V.V., Holocene of Novosibirsk islands, Mater. VI Vseross. soveshchaniya po izucheniyu chetvertichnogo perioda "Fundamental'nye problemy kvartera: itogi izucheniya i osnovnye napravleniya dal'neishikh issledovanii" (Proc. VI AllRuss. Meeting on the Study of Quaternary Period "Fundamental Problems of Quaternary: Results and Prospective Studies”), Novosibirsk, 2009b, pp. 38-40.

Arkhangelov, A.A., Mikhalev, D.V., and Nikolaev, V.I., Reconstruction of conditions of permafrost and paleoclimate in Northern Eurasia, in Razvitie oblastei mnogoletnei merzloty i periglyatsial'noi zony severnoi Evrazii $i$ usloviya rasseleniya drevnego cheloveka (Development of the Regions of Permafrost and Periglacial Zone of the Northern Eurasia and the Settlement Pattern of Ancient Man), Moscow: Inst. Geogr., Ross. Akad. Nauk, 1996, pp. 85-109.

Barinova, S.S., Medvedeva, L.A., and Anisimova, O.V., Bioraznoobrazie vodoroslei-indikatorov okruzhayushchei sredy (Biological Diversity of Algae-Environmental Indicators), Tel Aviv: Pilies Studio, 2006. 
Battarbee, R.W., Diatom analysis, in Handbook of Holocene Paleoecology and Palaeohydrology, Berglund, B.E., Ed., New York: Wiley, 1986, pp. 527-570.

Belevich, A.M. and Kuklina, T.A., Species composition, stratigraphic and paleogeographic role of diatoms from Quaternary deposits of the northern part of West Siberian Lowland and adjacent regions, Uch. Zap. Nauchno-Issled. Inst. Geol. Arkt., Paleontol. Biostratigr., 1970, no. 30, pp. 34-39.

Birks, H.J.B., Quantitative palaeoenvironmental reconstructions, in Statistical Modeling of Quaternary Science Data. Technical Guide 5, Cambridge: Quat. Res. Assoc., 1995, pp. 161-254.

Cremer H. and Wagner B. The diatom flora in the ultra-oligotrophic Lake El'gygytgyn, Chukotka, Polar Biol., 2003, vol. 26, no. 2, pp. 105-114.

Davydova, N.N., Diatomovye vodorosli-indikatory prirodnykh uslovii vodoemov v golotsene (Diatoms as the Indicators of Natural Conditions of Reservoirs in Holocene), Leningrad: Nauka, 1985.

Frolova, L., Subfossil Cladocera (Branchiopoda, Crustacea) in climatic and palaeoenvironmental investigations in Eastern Siberia (Russia), Proc. Conf. SGEM 2016, June 28-July 6, 2016, Albena, 2016, book 4, no. 2, pp. 601-606.

Gavrilova, M.K., Klimat Tsentral'noi Yakutii (Climate of Central Yakutia), Yakutsk: Inst. Merzlotoved., Akad. Nauk SSSR, 1973.

Genkal, S.I., Kulikovskii, M.S., Mikheeva, T.M., Kuznetsova, I.V., and Luk'yanova, E.V., Diatomovye vodorosli planktona reki Svisloch' $i$ ee vodokhranilishch (Planktonic Diatoms in the Svisloch' River Basin), Moscow: Nauchnyi Mir, 2013.

Grigor'ev, M.N. and Kunitskii, V.V., Glacial complex of the Arctic coast of Yakutia as the source of silts on shelf, Tr. Arkt. Reg. Tsentra, 2000, vol. 2, no. 1, pp. 109-116.

Hammer Ø., Harper D. A.T, and Ryan P.D. PAST: Paleontological statistics software package for education and data analysis, Palaeontol. Electron., 2001, vol. 4, no. 1, p. 9.

Juggins, S., C2 Version 1.5 User Guide. Software for Ecological and Paleoecological Data Analysis and Visualization, Newcastle: Newcastle Univ., 2007.

Kagan, L.Ya., Diatomovye vodorosli Evro-Arkticheskogo regiona (Diatoms of European Arctic Region), Apatity: Kol'sk. Nauch. Tsentr, Ross. Akad. Nauk, 2012.

Krammer, K. and Lange-Bertalot, H., Bacillariophyceae. Teil 1: Naviculaceae, in Süßwasserflora von Mitteleuropa, Stuttgart: Gustav Fischer Verlag, 1986.

Krammer, K. and Lange-Bertalot, H., Bacillariophyceae. Teil 2: Bacillariaceae, Epitemiaceae, Surirellaceae, in Süßwasserflora von Mitteleuropa, Stuttgart: Gustav Fischer Verlag, 1988.

Krammer, K. and Lange-Bertalot, H., Bacillariophyceae. Teil 3: Centrales, Fragilariaceae, Eunotiaceae, in Süßwasserflora von Mitteleuropa, Stuttgart: Gustav Fischer Verlag, 1991a.

Krammer, K. and Lange-Bertalot, H., Bacillariophyceae. Teil 4: Achnanthaceae, Kritische Erganzungen zu Navicula (Lineolatae) und Gomphonema. Gesamtliteraturverzeichnis, in Süßwasserflora von Mitteleuropa, Stuttgart: Gustav Fischer Verlag, 1991b. Kunitskii, V.V.,
Glacial complex and cryoplanation terraces of the Bol'shoi Lyakhovskii Island, in Problemy geokriologii (Geocryology), Yakutsk: Sib. Otd., Ross. Akad. Nauk, 1998, pp. 60-72.

Makeev, V.M. and Pitul'ko, V.V., New data on environmental conditions in the end of Late Pleistocene-Early Holocene in high altitude Asian Arctic and the period of settlement by ancient man, Dokl. Akad. Nauk SSSR, 1991, vol. 319, no. 2, pp. 435-437.

Nazarova, L., Herzschuh U., Wetterich, S., Kumke, T., and Pestrjakova, L., Chironomid-based inference models for estimating mean July air temperature and water depth from lakes in Yakutia, northeastern Russia, J. Paleolimnol., 2011, vol. 45, pp. 57-71.

Nazarova, L., Lüpfert, H., Subetto, D., Pestryakova, L., and Diekmann, B., Holocene climate conditions in Central Yakutia (North-Eastern Siberia) inferred from sediment composition and fossil chironomids of Lake Temje, Quat. Int., 2013, vols. 290-291, pp. 264-274.

Nazarova, L., Self, A., Brooks, S.J., van Hardenbroek, M., Herzschuh, U., and Diekmann, B., Northern Russian chironomid-based modern summer temperature data set and inference models, Global Planet. Change, 2015, vol. 134, pp. 10-25.

New, M., Lister, D., Hulme, M., and Makin, I., A highresolution data set of surface climate over global land areas, Clim. Res., 2002, vol. 21, pp. 1-25.

Palagushkina, O.V., Nazarova, L.B., Wetterich, S., and Shirrmaister, L., Diatoms from sediments of water bodies of Siberian Arctic, Contemp. Probl. Ecol., 2012, vol. 5, no. 4, pp. 413-422. doi 10.1134/S1995425512040105

Palagushkina, O.V., Nazarova, L.B., and Frolova, L.A., Diatoms from the Holocene deposits of the Bol'shoi Kharbei Lake (Bol'shezemel'skaya tundra, Russia), $Z$ h. Sib. Fed. Univ., Biol., 2014, no. 7, pp. 395-410.

Paul, C.A., Rühland, K.M., and Smol, J.P., Diatominferred climatic and environmental changes over the last 9000 years from a low Arctic (Nunavut, Canada) tundra lake, Palaeogeogr., Palaeoclimatol., Palaeoecol., 2010, vol. 291, pp. 205-216.

Pirumova, L.G., Diatoms of Quaternary deposits of the northern part of Yana-Indigirka Lowland and Bol'shoi Lyakhovskii Island, in Iskopaemye diatomovye vodorosli SSSR (Fossil Diatoms of Soviet Union), Moscow: Nauka, 1968, pp. 80-83.

Potapova, M. and Charles, D.F., Distribution of benthic diatoms in U.S. rivers in relation to conductivity and ionic composition, Freshwater Biol., 2003, vol. 48, pp. $1311-1328$.

Rapoport, L.G. and Romanovskii, N.N., Paleogeography of Quaternary period of the northern coast of YanaIndigirka Lowland by diatom flora, Vopr. Fiz. Geogr. Polyarn. Stran, 1959, no. 2, pp. 196-203.

Romanovskii, N.N., Paleogeographic conditions of formation of Quaternary deposits of the Bol'shoi Lyakhovskii Island (Novosibirsk islands), Vopr. Fiz. Geogr. Polyarn. Stran, 1958, no. 1, pp. 80-88.

Rouillard, A., Michelutti, N., Rosén, P., Douglas, M.S.V., and Smol, J.P., Using paleolimnology to track Holocene climate fluctuations and aquatic ontogeny in poorly buffered high Arctic lakes, Palaeogeogr., Palaeoclimatol., Palaeoecol., 2012, vols. 321-322, pp. 1-15. 
Rühland, K. and Smol, J.P., Diatom shifts as evidence for recent Subarctic warming in remote tundra lake, NWT, Canada, Palaeogeogr., Palaeoclimatol., Palaeoecol., 2005, vol. 226, pp. 1-16.

Sorensen, T.J., A Method of Establishing Groups of Equal Amplitude in Plant Sociology Based on Similarity of Species Content and Its Application to Analyses of the Vegetation on Danish Commons, Biol. Skr.-K. Dan. Vidensk. Selsk., København: Kom. E. Munksgaard, 1948, vol. 5, no. 4.

Stenina, A.S., Diatoms in a peatbog polluted with oil-field brines in the Kolva River basin, Komi Republic, Contemp. Probl. Ecol., 2008, vol. 1, no. 4, pp. 449-453.

ter Braak, C.J.F. and Šmilauer, P., CANOCO Reference Manual and CanoDraw for Windows User's Guide: Software for Canonical Community Ordination (Version 4.5), Ithaca, NY: Microcomp. Power, 2002.

van Dam, H., Mertens, A., and Sinkeldam, J., A coded checklist and ecological indicator values of freshwater diatoms from the Netherlands, Aquat. Ecol., 1994, vol. 28, pp. 117-133.
Wetterich, S., Herzschuh, U., Meyer, H., Pestryakova, L., Plessen, B., Lopez, C.M.L., and Schirrmeister, L., Evaporation effects as reflected in freshwaters and ostracod calcite from modern environments in Central and Northeast Yakutia (East Siberia, Russia), Hydrobiologia, 2008, vol. 614, no. 1, pp. 171-195.

Wetterich, S. and Schirrmeister, L., Limnological studies in the Dmitry Laptev-Strait region, Rep. Polar Mar. Res., 2009b, vol. 584, pp. 155-163.

Wetterich, S., Schirrmeister, L., Andreev, A., Pudenz, M., Plessen, B., Meyer, H., and Kunitsky, V.V., Eemian and Late Glacial/Holocene palaeoenvironmental records from permafrost sequences at the Dmitry Laptev Strait (NE Siberia, Russia)., Palaeogeogr., Palaeoclimatol., Palaeoecol., 2009a, vol. 279, pp. 7395.

Zabelina, M.M., Kiselev, I.A., Proshkina-Lavrenko, A.I., and Sheshukova, V.S., Diatoms, in Opredelitel' presnovodnykh vodoroslei SSSR (Guide for Identification of Freshwater Algae in Soviet Union), Moscow: Sovetskaya Nauka, 1951, no. 4.

Translated by Ya. Lavrenchuk 